\title{
Marx’s 1844 Manuscripts and Humanism and Aesthetics: An Interview With Prof. Kevin B. Anderson*
}

\author{
WANG Jie \\ Zhejiang University, Zhejiang, China \\ YIN Qinghong \\ Shanghai Jiao Tong University, Shanghai, China
}

\begin{abstract}
The second Sino-British forum on Marxism aesthetics took place on April in University of Manchester with the theme Marxism and Humanities. During the conference both Prof. WANG Jie and Dr. YIN Qinghong had a chance to talk with Prof. Kevin Anderson about some issues related to the thought of the manuscripts and Humanities. Prof. Anderson introduced the editing work of MEGA and his new book Marx at margin.
\end{abstract}

Keywords: Max, 1844 Manuscripts, Marxism, humanism, aesthetics

Wang (Professor Wang Jie): In the past few days, we have had inspiring lecture and talks from you. We would like to ask you some questions that I think other Chinese scholars may be interested in. I know that you are the editor of a volume of the MEGA (Marx-Engels Gesamtausgabe or Complete Writings), an edition that many Chinese researchers are relying on. What do you think is the value of your MEGA work to modern Marxist studies?

Anderson: (Professor Kevin B. Anderson) A lot of people think that one aspect of the best Marxist research today is to look at what Marx writes and what Engels writes and to show they are not the same. For example, in the MEGA edition of Capital, they published all the draft manuscripts and then they also published Vols. 2 and 3 Capital the way Engels has edited them so scholars can see more clearly what Marx actually wrote. And then there are other parts of the MEGA that are totally new, unknown even to most Marx scholars. That is the part I am personally working on, which is called the excerpt notebooks. These notebooks form part 4 of the MEGA. These are Marx's research notebooks.

Wang: Many versions of the publications are indeed trying to compete and to define who is closer to Marx original words and thoughts. Today, in your lecture, you introduced Marxism and Humanism in the USA; after your lecture, people also raised questions about the connection between Marxism and Humanism. I don't know if you are aware that in China, the relation between Marxism and Humanism is a very important and very sensitive topic that it has led to many discussions and fierce debates. I would like to hear your views on the relationship between Marxism and Humanism.

\footnotetext{
* Acknowledgements: This paper was sponsored by China National Social Science Foundation "Research on the Fundamental Problems of the Contemporary Aesthetics and Criticism Patterns” (15ZDB023).

WANG Jie is the Qiushi Distinguished Professor and Yangtze River Scholar Professor of Ministry of Education in College of Media and International Culture, Zhejiang University. His research field covers Marxism aesthetics and cultural theory, aesthetic ideology, aesthetic illusion and the anthropology of aesthetics.
} 
Anderson: I come out of the school of Marxist Humanism in the U.S. It was founded by Raya Dunayevskaya. She was an American philosopher but born in Russia. I studied with her and two of her books are translated into Chinese, Philosophy and Revolution and Marxism and Freedom. But in both cases for the Chinese translation they left out the critical discussions regarding Mao Zedong. Earlier, in the 1950s, Dunayevskaya was the first person to translate the 1844 Manuscripts into English. That was in 1958. I studied with her in the 1970s and 1980s. In this tradition, Marx is always a humanist but in his 1844 writings, this was more open and explicit. For example, you have alienation in 1844; but then in Capital you have fetishism of the commodity. Thus these themes continue; it is just that the late Marx does not express his Humanism as openly. Another issue linked to humanism is Hegelianism. Again, in 1844 the link to Hegel is more explicit. But if you know Hegel and you know the 1844 Manuscripts, then you can see these themes throughout Marx work. Some people call themselves Structuralist Marxists, or Analytical Marxists, and for a similar reason I call myself a Marxist Humanist.

Wang: You may know that after 1989 Louis Althusser had a huge impact in China. Even in the 1980s when China was discussing the 1844 Manuscripts Althusser's reputation was high. He said the 1844 Manuscripts reflect Marx as a Humanist but not a true Marxism. He proposed the two-fold division in Marx's writings. I would like to hear your view on Louis Althusser's interpretation of Marx.

Anderson: A lot of his interpretation on Marx is mistaken. I don't think it is really possible to make this separation between the young Marx and the later Marx. Because for example Althusser said that the German Ideology is the real Marx whereas 1844 Manuscripts is the young Marx. But two years after the German Ideology, Marx and Engels published The Communist Manifesto, in 1848. In the Communist Manifesto he talked about class struggle, of course, but also he talked at one point about "the free development of each as the condition of the freedom of all”. Again, when Althusser reads Capital, he wants almost to disregard chapter one of the Capital. He said we should not really read this part of Marx when beginning to study Capital, but read it later. My first book is on Lenin. Lenin says in order to understand Marx’s Capital you have to read the whole of the Hegel's Logic. But Althusser turned Lenin's statement around; he said what it really meant is in order to understand Hegel you need to read Marx. Althusser is really part of a French tradition that is only partly Marxist. There are lots of French rationalists, from Descartes onward. The kind of strict categories Althusser wants are sometimes incompatible with dialectical thinking. Althusser actually writes very little about dialectical thinking. He avoids this word almost completely. At most he just wants to talk about contradiction. But what is contradiction? In Hegel and Marx, contradiction is related also to negation of the negation, which not only negates, but also moves in a positive direction. When Althusser comments on the end of Capital, where Marx uses the Hegelian term negation of the negation, he objects even to this. Thus, I would say Althusser is only partly a Marxist, and that he is also part of the French rationalist tradition.

Wang: Do you think Althusser is theoretically wrong?

Anderson: His understanding of Marx is wrong; more of it is wrong than right.

Wang: My understanding is that Althusser's argument comes from one of the main theories of Marx, which is also stated in The Communist Manifesto and that is Marxists must completely break away from the capitalist tradition and the capitalist traditional way of production. In Althusser's, as well as many Chinese anti-Humanists' view, Marxists must fight against and break away from the traditional ways of thinking and from the Humanists, including people like Shakespeare and Schiller. Marx did express this view in Manifesto so what do you think of the two "breaks"? 
Anderson: There are at least three kinds of Humanism. There is the Humanism of Shakespeare, and that of Machiavelli. This is Renaissance Humanism. The Italian humanists Niccolo Machiavelli and Leonardo da Vinci exemplify Renaissance Humanism. This humanism is interested in concrete human reality. It is materialist, somewhat materialist. But it really does not have a concept of wanting to radically changing human nature, of how human nature could become better. It's a bit cynical almost. Then you have the Enlightenment Humanists, and they talk about the ideal society, how we are born free, we are good, but then society corrupts us. Therefore we should try to return the state of nature. But Enlightenment Humanism is also forward-looking, it wants to create a better human being, a better world, and it is therefore revolutionary. But you could say it's too idealistic. So the first one is too materialistic, and the second too idealistic.

Then starting with Hegel, and later, Marx, you have a social type of Humanism. Instead of asking whether something is ideally possible; they ask what is really possible. Of course for Marx this is about the proletarian under capitalism, and in the Manifesto he does support capitalism a little bit, against the old feudal society. In other words, it's a more practical philosophy but there is still a certain element of idealism in it too. I know Marx always said he is materialist, but in 1844 he admits that he is also an idealist. So I see Marx's dialectic as a unity of idealism and materialism. There is an idealist element in it; otherwise, it's just a very practical Humanism. Human beings are human, true. But what is truly humanist? What are the possibilities, not as a dream, but as a real possibility? This really all starts with Hegel because Hegel is a historicist philosopher.

Wang: You constantly put Marx and Hegel together; do you think Hegel and Marx share many similar views on Humanism?

Anderson: Yes there are similarities. I think we need to emphasize them a lot, for example the dialectic. Fundamentally, it is really the same dialectic for Hegel and Marx. Marx said in Capital that Hegelian dialectic is the source of all dialectic. This is not the young Marx. He says this is what's wrong with John Stuart Mill; he doesn't really understand dialectic. But at the same time the focus is different for Marx. Marx is interested in the whole human being, spiritual, bodily, everything. For example, when Hegel writes in the Phenomenology about the slave, he is very sympathetic to the slave. He hits out at the master; he thinks the slave develops critical consciousness as the result of being a slave that as a result of his suffering the slave gets a more critical view of society. But what is the end result for Hegel in that chapter? It is that the slave develops self-consciousness. But for Marx, the point would also be whether the slaves are going to be free in reality. You need critical consciousness but you also need actual freedom. You need material freedom. For Hegel the most important result of all these material struggles is a higher form of consciousness. Hegel is interested in real human freedom too but this is less important to him than consciousness. He is also a materialist up to a point. Concerning Stoicism, for example, Hegel says it was a very important advance in philosophy for its time period, for the period of the Roman Empire. It is one of the highest forms of consciousness you can get, for at that time in the real world no one is free. So he historicizes it. It would not be a great philosophy today that is for Hegel's own time period, but it's a great philosophy for 1,500 years ago. In this way, he is not totally different from Marx, in saying that philosophy is conditioned by material circumstances. Hegel would agree with Marx that philosophy is conditioned by social and material circumstances. Here he and Marx are very similar.

Engels created a big problem for us on these issues. In his 1886 essay on Ludwig Feuerbach, Engels says there are two types of philosophers, the materialists and the idealists, and that we are on the side of the former. However, some of the materialists are reactionary; fascists can be materialists, for example. Some idealists can be reactionary and some can be progressive. But it is made too easy for us by Engels. For example, what is art? 
Is art just the reflection of the world? Is aesthetics the same thing as sociology? Are they the same thing or does art have a relative autonomy from the social structure? It's conditioned by the social structure but sometimes rises above it. Was it in your paper that you talked about the Greeks? That Marx wrote in the Introduction to the Grundrisse that their art was ahead of their material circumstances. This is the problem with Engels. Engels personally understood Hegel, but the way he tried to popularise dialectics, to simply it, created problems. If you look at the first chapter of my book on Lenin, you will find my views about these problems.

Wang: You mentioned there are many differences between Marx and Engels. In your view, in aesthetics what are the different views between Marx and Engels? As far as I know Marx and Engels have both debated on Raphael Holinshed's theatrical script. Do you think Marx and Engel's views on art are similar? Or are their views different, as on Humanism?

Anderson: I don't think Engels has written anything significant on aesthetics. Let me add this though: I am not against Engels. I think some philosophers like Jean-Paul Sartre are too negative about Engels, portraying him as a negative influence on Marx. Or Georg Lukács, who says there is no dialectic nature, and that Engels was wrong. In Western Marxism, there are a few who believe that Engels is just wrong. I don't agree with that. I see several very important contributions by Engels. One of the issues, as I wrote about in my recent book Marx at the Margins, concerns Poland, the Irish, and his sensitivity towards national oppression and nationalist movements. Engels was very good on national oppression on the oppression of ethnic minorities like the Irish in Britain; and also against colonialism, as when he wrote, alongside Marx, about the Second Opium War in China. That is one thing. Secondly, Engels has great sensitivity towards the peasantry. This is seen in his book on peasant war in Germany; its $16^{\text {th }}$ century peasant uprising was very important. A third contribution from Engels was his editing of vols. 2 and 3 of Capital. Today you could question the way he edited maybe, but without these efforts, I don't think we would have Marxism. You can raise questions about it but it was really necessary. Those who came after Engels, like Kautsky, were incapable of this type of editing of Marx. Also, Engels really developed the critique of political economy before Marx. Moreover, his 1844 book on the working class in Manchester was really, really important. So there are many important parts of Engels's work. More generally, however, I don't think any of these people after Marx, that is to say Engels, Lenin, and Trotsky, let alone Mao and Althusser, were able to measure up to Marx. Marx is the truly original thinker. Very few, since the beginning of human history, are original thinkers like Marx. So if we really understand Marx we have to critique all these people who came after and we also have to read Marx directly. We will find problems and differences we should not be afraid of this. I know in China they say Marx, Engels, Lenin, Mao, Stalin, Deng Xiaoping, so if you question Engels you will put a crack in this succession of thinkers after Marx. This clinging to such a succession is a religious but not a scientific way of thinking.

Wang: You are very familiar with the 1844 Manuscripts. One of the main theoretical points for Marx in 1844, which has generated many debates amongst Chinese scholars, is that when Marx discusses human production, he emphasized that human production is based on aesthetics. He compared human beings with animals. This is a topic of debate in China. I would like first to hear your views on the laws of beauty; secondly, is there any connection between Marx's view on the laws of beauty and Humanism? I personally think there is a connection.

Anderson: I think we have two parts of Marx we need to look at. One is this (1844) and another is Capital. Here in 1844 he says free conscious activity is the species being [Gattungswesen in German] of the human being. If I were making the translation I would call it the "species essence". Because this is how we normally 
translate this German word, Wesen. This is what differentiates human beings from other animals, because they don't have free conscious activity. They produce based mainly on instinctual patterns. There is a certain beauty to their production, of course. I think what is built by animals can be beautiful to look at. But it is the beauty of nature, which is different from human creation. I think Marx clarifies this in Capital, in chapter 7 of the English version Capital, on the valorisation process, the realisation of value. At the beginning on that chapter, in a very famous paragraph, he compares the labour of human beings with the labour of spiders and bees. He says the spider might create a beautiful web, but he repeats the same pattern each time, whereas human beings can view their creations in the imagination before constructing them in reality. We are also capable of changing our physical environment and changing ourselves at the same time. Sometimes we create ugliness, but sometimes we create a beauty greater then natural beauty. Sometimes we consider something we have created to be ugly, but if we wait another hundred years, sometimes we find its beauty. Because sometimes these are done by avant-garde artists, which is why they are called avant-garde. This is the same word as vanguard, the sense of the vanguard party as espoused by Lenin. I am not an aesthetician and that is all I can say. Sorry.

Yin (Ying Qinghong): I have a question about 1844. More and more unpublished documents have been found on Marx's work. Have you found any other unpublished papers on 1844 or have we got a completed 1844 ?

Anderson: I think we have the complete texts now from 1844. If you look at the MEGA edition of the 1844 Manuscripts, which was published some 20 years ago, the editors give two versions. In the original version, Marx wrote text in several columns on the same page, discussing different things at the same time. How, then, do you put them together? In the 1920s version published in Russia that became the basis for subsequent editions of the 1844 Manuscripts, the essay that the editors entitled "Critique of the Hegelian Dialectic" begins by talking about Feuerbach for a couple pages and then starts to talk about Hegel's Phenomenology. The 1983 MEGA edition reveals that the short text on Feuerbach came from a different part of Marx's Manuscript than the longer part on Hegel. Thus, somebody in Moscow in the 1920s decided those two belonged together, but in the new MEGA we can see the separation. That is one thing. A second new thing in the MEGA related to 1844 can be found in Vol. IV/3 of the MEGA, published about a decade ago. It has a lot of Marx's notes on political economy from 1844 and 1845. In these notes you can see what economic writers he was reading. Much of it is in French, because Marx didn't know English well yet and he was reading Adam Smith in French. The 1844 Manuscripts are not the same thing as the notebook of 1844-45, however. In the notebook all he was doing was writing down quotations from other writers, with very few comments of his own. Sometimes he writes a one-sentence comment and then five pages of quotations. You can't call them manuscripts, as they are his research notebooks. Those are from that period. Pretty much all from $1830^{\text {th }}$ has been published.

Yin: Maybe when Marx was writing the Manuscripts of 1844, he did not have the complete logic across the whole writing?

Anderson: It's less organised as a text in the MEGA version of the 1844 Manuscripts than these writings are presented in the way they came down to us. But I think it's published in Chinese already in the more complete MEGA version I talked about.

Yin: In China, before 1956 only parts of his manuscripts were translated. In 1956 his entire manuscripts was translated and published in the form of a book. Since then, different scholars have been revising the translation of the manuscripts. In 1979, the translated Chinese manuscripts become the definitive copy of his work. 
Anderson: If so, that is more or less the 1932 version from German, which everyone has had for the past 80 years. This is the one published in Moscow in 1932 in German. As I mentioned, in 1983 in German in the MEGA, another version of this was published; this was the one shown in three columns. You don't have to go to unpublished manuscripts for it, as it's in the MEGA now. I believe that one of Chinese professor told me that that has been translated into Chinese too for more or less ten years. I think they are translating all Marx and Engels's texts from the MEGA into Chinese.

Wang: Yes, we have translated 54 volumes, from German version.

Anderson: Is it from Marx's shorter collected works or from MEGA?

Wang: From MEGA.

Anderson: Perhaps that is all there is. Because in MEGA there is supposed to be about 120 volumes, but only about 50 of them have been published. I will not live to see them finished. You young people will maybe see it finished.

Yin: Are there many of other books have not been published yet?

Anderson: This is because there is not enough funding to do it. Under the German Democratic Republic (DDR) they had hundreds of people working on the MEGA, with full salaries and everything. Now they are only a small number. Similarly, the Hegel Gesamtausgabe is not finished either. Sometimes, German scholars work very slowly. If someone in China or elsewhere wants to give the MEGA project a lot of money I am sure they will be finished sooner. There is some money from the German state but not a lot.

Yin: Last year, the library of Shanghai Jiaotong University bought some MEGA volumes.

Anderson: We even got some money from America for the MEGA. I got some money from the United States National Endowment for the Humanities to do one volume of the MEGA. We paid scholars; we worked with a Russian-American group. We worked on notebooks from the end of Marx's life, which were on India and on other pre-capitalist societies. But this volume not finished yet. We are still working on it. We spent the money but we still have much more to do. I have to work on my own on it during the summertime, and the others under similar circumstances.

Wang: We were talking to Macdonald Daly about documents on Marxist aesthetics ${ }^{1}$ from around the world; do you think there might be any connection between our work and yours?

Anderson: I don't think directly too much, because, unlike me, so many people in the $20^{\text {th }}$ century wrote on Marx and art. In the West there is always a link between aesthetics and philosophy. Most of the great Marxist philosophers are also writing on art like Marcuse, Adorno, even Althusser. Probably with the MEGA we will get more letters and texts on Marx himself on art. I am sure there must be something we have never seen before in all those notebooks. Maybe there are some notebooks on Shakespeare. I don't know. A lot of

${ }^{1}$ Documents on Marxist Aesthetics (DOMA) was initially planned by Lee Baxandall and Stefan Morawski in the 1960s as a twelve-volume series whose purpose was to document and analyse the achievements and evolution of Marxist thought on literature, drama and art during its period of classical development from Marx and Engels in the mid-nineteenth century through its major representatives in England, France, Germany, Holland, the USSR and the USA until 1925.Much of the work for these and later volumes was completed but never saw the light of day. Instead, the materials have languished for several decades in a battery of filing cabinets in the the possession of Lee Baxandall. In 1999, Lee Baxandall and Stefan Morawski kindly gave permission to Dr. Macdonald Daly, who is a Marxist and a Senior Lecturer in Nottingham University, to revise, republish and to explore the surviving archive of materials.The first volume is Karl Marx and Frederick Engels on Literature and Art. A selection of writings edited by Lee Baxandall and Stefan Morawski, with an Introduction by Stefan Morawski, was published in 1974 by International General (New York).Revised edition, with supplementary notes, index and a new Introduction, “A Short History of Marxist Aesthetics", by Macdonald Daly and published in Great Britain by Critical, Cultural and Communications Press, Nottingham, 2006. Professor Wang Jie and Dr. Macdonald Daly have come to an agreement about cooperate work on this project. 
things we don't know because his notebooks are going to be 40 volumes in the MEGA when it is finish and so far only about 10 of these have been published.

Wang: The full volumes of Chinese Marxist collection is translated from Russian.

Anderson: I think some large parts of the MEGA are or will be in Chinese. I know the Americans are not translating it into English because we don't have the money. For my MEGA volume, we are going to translate it into English. But this is not typical for the MEGA; it is because we got the money from the United States for this volume.

Wang: Could you please talk a little about the main concepts of your new book Marx at the Margins?

Anderson: This book is a survey, a discussion of what Marx wrote about precapitalist societies at that time: India, China, Indonesia, North Africa, Latin America, etc. It's also about what he has to say about ethnic and national problems: the Irish in Britain; Ireland, Poland, and other national liberation movements; also his writings on race and ethnicity during the Civil War in America. So it is Marx on nationalism, ethnicity, and also non-Western and precapitalist societies. It includes what he said about Russia too. The argument of my book is that first of all, Marx is not just concerned about the working classes. In a country like America he sees the racial division inside the working class, between the blacks and the whites. In a country like England, he sees the division between the Irish workers and the English workers. In the case of Ireland and Poland he sees what we later call national liberation. He saw that as very important to the global struggle against capitalism. Finally, in places like India and Russia he saw the possibility of a peasant-based revolution, but only on the condition that it would be linked up with the Western proletariat. He didn't think it was possible to build socialism in rural country like Russia at the time; this could be done only if Russian revolutionaries could ally with the Western labour movement. Lenin for example wrote about these problems too, but Lenin wrote mainly about global finance capital. He looked at it at it more global level, whereas Marx was very interested in the class struggle within the society. He spent decades writing about Ireland, India, and Russia. He even learned Russian, reading detailed texts on agriculture in Russian in the 1870s and 1880s. Thus, Marx's ideas about revolution and about the working class are more complicated than we usually realize. It's very important to look at this because of some critics of Marx's Eurocentrism such as Edward Said. Said is partially right concerning the Communist Manifesto, or when or when Marx was writing about India on the New-York Tribune, there were lots of problems. But what I try to show in my book is that Marx's thinking evolved and he later becomes much less Eurocentric; he adopts a more global view. At the end of his life, he was taking more notes on India than on Western capitalism. We don't know what he was going to write about on the basis of those notes on India at the end of his life, 1879-82. In this period, he made a lot of notes on Russia too. One German thinker said Marx turned his eyes to the east at the late in his life. He did not write much on China at that point, but concentrated on India, and to an extent, Indonesia. However, there might be some notes on China somewhere in the unpublished notebooks of Marx that we don't know about.

Wang: I am also very interested in these topics about Marx later life and his notes on the East and on non-capitalist society. This seems to be what is called using an anthropological approach to research Marxism and Humanity. There is a saying called Marx humanist transition. In his early period, such as 1844, there seems to be such concept called aesthetic humanism. It is based on philosophy, but combine philosophy and anthropology. A typical example could be seen in the Law of Beauty. I wonder if there is a link between early Marx work on philosophical anthropological study and aesthetics anthropology with his later research on 
anthropology and non-capitalist societies. Many Chinese scholars believe there are connections but could not provide theoretical proves.

Anderson: I thought about this a lot too but I don't have an answer for it. I guess one thing you can say is that in 1844 he has a much wider range of concerns. Later on he writes Capital, Vols. I-III and the Theories of Surplus Value. He had a clear focus on the critic political economy during the 1850s and 1860s, but then at the end of his life, his concerns became much wider again. Engels was very angry when he looked at Marx's papers after his death. He was shocked. He said he was writing about so much in all those notebooks, all these different things, but he never finished Capital. Engels said if he had known about this, he would have pushed him to finish Capital. The chief editor of Marx in Russia in the 1920s, David Riazanov, was the one who gave us the first MEGA. He gave us the German Ideology, the 1844 Manuscripts, etc. He was the editor of all of them. He found Marx's excerpt notebooks, especially those at the end of his life on India and Indonesia, and he asked why Marx was spending his time on these topics, on these not so important topics? And then he said maybe it was because he no longer had the intellectual capacity to work on political economy. So this is Eurocentrism. I quote all these statements in my book, as we have to go beyond that kind of Eurocentrism if we want to understand Marx, especially for today.

Wang: Thank you very much for your time answering the questions.

Anderson: Thank you for your questions. 